\title{
A key for the description of Palaeozoic ammonoids
}

\author{
Dieter Korn
}

Museum für Naturkunde Berlin, Invalidenstraße 43, 10115 Berlin, Germany. E-mail: dieter.korn@mfn-berlin.de

\begin{abstract}
Received 4 June 2009

Accepted 12 September 2009

Published 19 February 2010

\section{Key Words}

A key for the description of Palaeozoic ammonoids is presented. It contains a catalogue of descriptive terms to characterise conch morphology, ornament, and suture line particularly of Carboniferous ammonoids. A number of examples of tables and illustrations are given for the description of conch characters, their ontogeny and intraspecific variability.
\end{abstract}

\author{
Ammonoidea \\ Carboniferous \\ morphology \\ ontogeny \\ taxonomy
}

\section{Introduction}

Palaeozoic ammonoids have been described for almost 200 years. Since the first nomination of the Carboniferous ammonoid "Ammonites Listeri" by Sowerby (1812), styles and contents of descriptions have significantly been modified and completed. The numbers of conch characteristics taken into account have increased considerably, and external as well as internal characters were evaluated to form a balance. While the early authors mainly described more or less mature stages of single individuals, later authors also included the ontogeny of specimens and or the variability within populations.

Although there is a sort of consensus among ammonoid workers about the use of the various conch characters and their importance for ammonoid description and classification, there is no agreement on how species should be characterised in terms of diagnoses and illustrations. It was particularly Ruzhencev (e.g. 1956, 1960), who in a series of monographs, developed a standard for ammonoid descriptions accompanied by illustrations of representative specimens on plates, well-drawn suture lines of mature and often of juvenile stages, and occasionally also conch cross sections. His diagnoses and descriptions of species followed a strict scheme, in which all the important characters were outlined.

Based on the study of Permian forms, Kutygin (1998) has proposed a scheme for the description of ammonoid conchs. In a bivariate diagram he showed the conch width index and umbilical width index and separated between 35 possible morphs. He named these morphs either according to their shape (e.g. 'sferokon', 'kadikon') or after ammonoid genera (e.g. 'oppellikon', 'daktilikon'); name pairs such as 'ofikon' (for very slender forms) and 'subofikon' (for moderately slender forms) lead to a reduction of descriptive terms.

The description key outlined here can be seen as a further development of the schemes proposed by Ruzhencev and Kutygin. This key is specifically coined for the Early Carboniferous ammonoids from Algeria, which will be described in monographs of this volume (Bockwinkel et al. 2010; Ebbighausen et al. 2010; Korn et al. 2010a, 2010b, 2010c); it was developed mainly for Carboniferous ammonoids of the predominant suborder Goniatitina, which has a wide morphological range but very similar suture lines.

\section{Conch characteristics}

\section{Conch geometry}

Descriptive terms of the conch characters are mainly adopted, with some modifications, from Korn \& Klug (2003, 2007), who outlined the morphological spectrum for Devonian ammonoids. Cross-sections have the highest potential for providing a large data set for morphometric analysis of ammonoid conchs. With a reasonable number of cross-sections, ontogenetic development as well as in- 


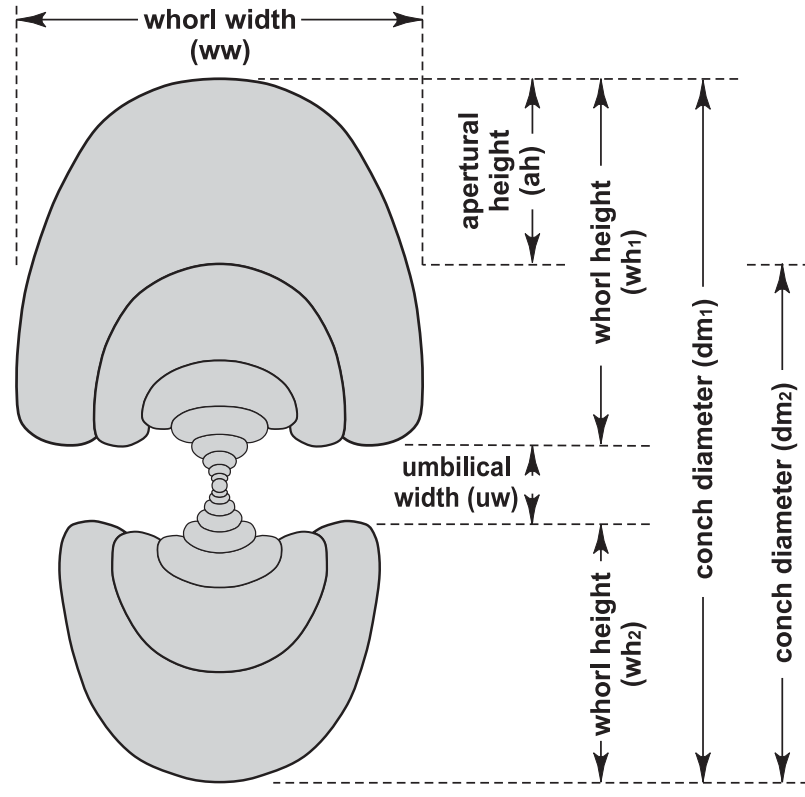

Figure 1. Descriptive terms for conch morphology of Palaeozoic ammonoids.
Table 1. Classification of the maximum conch diameters of individual specimens.

\begin{tabular}{lc}
\hline descriptive term & maximum diameter \\
\hline very small & $<25 \mathrm{~mm}$ \\
Small & $25-50 \mathrm{~mm}$ \\
moderate & $50-100 \mathrm{~mm}$ \\
Large & $100-200 \mathrm{~mm}$ \\
very large & $>200 \mathrm{~mm}$ \\
\hline
\end{tabular}

Table 2. Classification of the general conch shape (conch width index; ww/dm); see Fig. 2.

\begin{tabular}{lc}
\hline descriptive term & ww/dm \\
\hline extremely discoidal & $<0.35$ \\
discoidal & $0.35-0.60$ \\
pachyconic & $0.60-0.85$ \\
globular & $0.85-1.10$ \\
spindle-shaped & $>1.10$
\end{tabular}

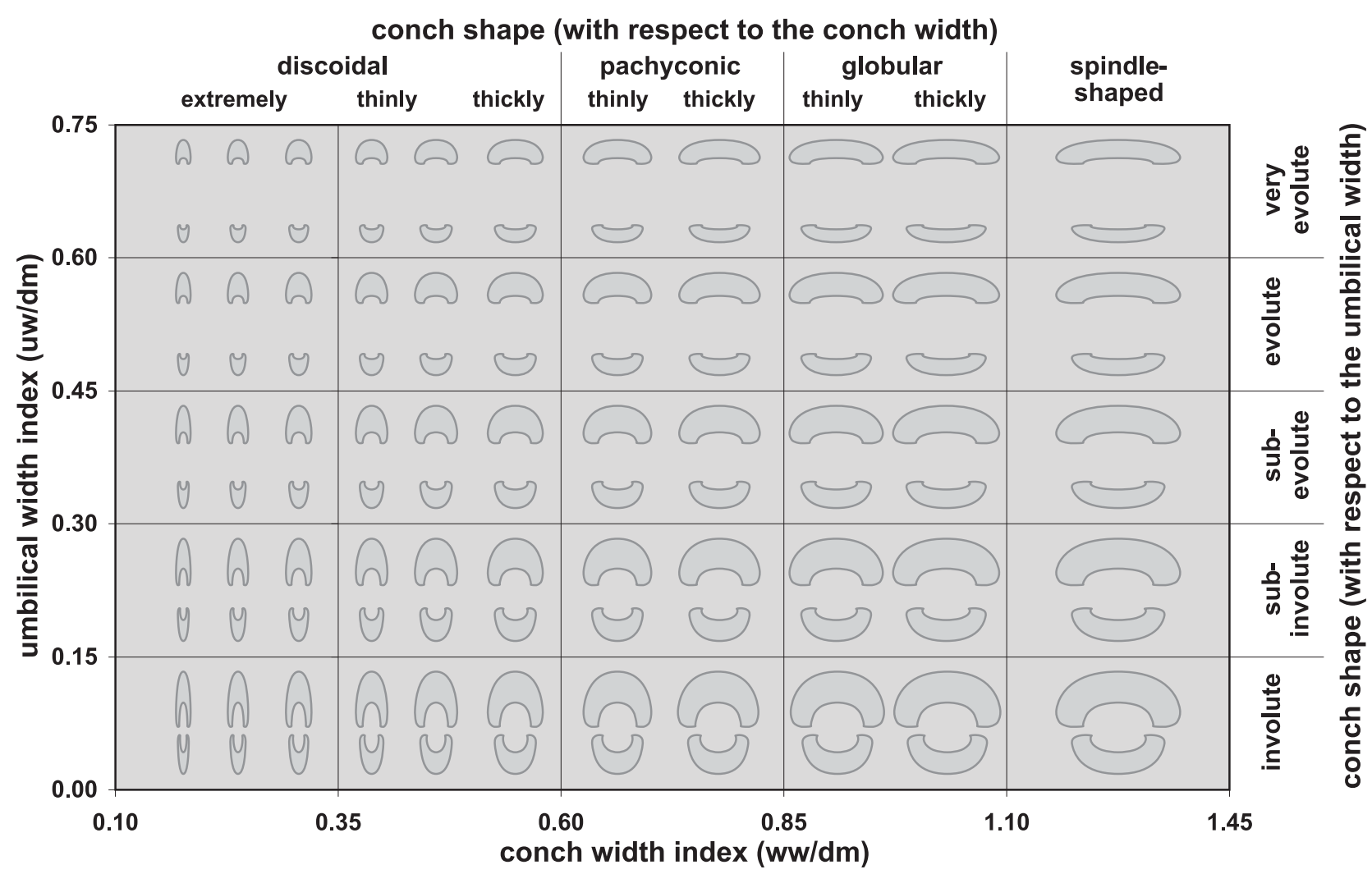

Figure 2. Bivariate plot illustrating the terminology of the conch width index (ww/dm) on the $x$-axis and umbilical width index (uw/dm) on the $y$-axis.

traspecific variability can be analysed for a number of species or complete assemblages. From computer drawings of the cross-sections, three of the basic conch parameters can immediately be obtained for each half volution (Fig. 1):

- conch diameter $\left(\mathrm{dm} ; \mathrm{dm}_{1}\right.$ is the largest diameter in a cross section and $\mathrm{dm}_{2}$ is the diameter exactly half a whorl earlier)
- whorl width (ww; $w_{1}$ and $w_{2} w_{2}$ as above)

- whorl height (wh; $w_{1}$ and $w_{2}$ as above)

Using these basic parameters, secondary parameters can easily be computed:

- umbilical width (uw) $=\mathrm{dm}_{1}-\mathrm{wh}_{1}-\mathrm{wh}_{2}$

- aperture height $(\mathrm{ah})=\mathrm{dm}_{1}-\mathrm{dm}_{2}$ 
- imprint zone width (iz) $=\mathrm{wh}_{1}-$ ah or $\mathrm{wh}_{1}-\left(\mathrm{dm}_{1}-\mathrm{dm}_{2}\right)$

Conch proportions and expansion rates (growth rates) were calculated in the following way by using the three basic conch parameters:

- conch width index $(\mathrm{CWI})=\mathrm{ww}_{1} / \mathrm{dm}_{1}$

- whorl width index $(\mathrm{WWI})=\mathrm{ww}_{1} / \mathrm{wh}_{1}$

- umbilical width index $(\mathrm{UWI})=\mathrm{uw} / \mathrm{dm}_{1}$ or $\left(\mathrm{dm}_{1}-\mathrm{wh}_{1}-\mathrm{wh}_{2}\right) / \mathrm{dm}_{1}$

- whorl expansion rate $(\mathrm{WER})=\left(\mathrm{dm}_{1 / 1 m_{2}}\right)^{2}$ or $\left[\mathrm{dm}_{1} /\left(\mathrm{dm}_{1}-\mathrm{ah}\right)\right]^{2}$

- imprint zone rate $(I Z R)=w_{1}-a h / w_{1}$ or $-\left(\mathrm{wh}_{1}\left(\mathrm{dm}_{1}-\mathrm{dm}_{2}\right)\right) / \mathrm{wh}_{1}$

The shape of the venter, the arrangement and the shape of the flanks, the umbilical margin and the umbilical wall can be thus described as broadly rounded, narrowly rounded, subangular, angular, and acute (Fig. 4).

Table 3. Classification of the whorl cross section shape (whorl width index; ww/wh); see Fig. 3.

\begin{tabular}{lc}
\hline descriptive term & Ww/wh \\
\hline strongly compressed & $<0.50$ \\
weakly compressed & $0.50-1.00$ \\
weakly depressed & $1.00-1.50$ \\
moderately depressed & $1.50-2.00$ \\
strongly depressed & $2.00-2.50$ \\
very strongly depressed & $2.50-3.00$ \\
extremely depressed & $>3.00$ \\
\hline
\end{tabular}

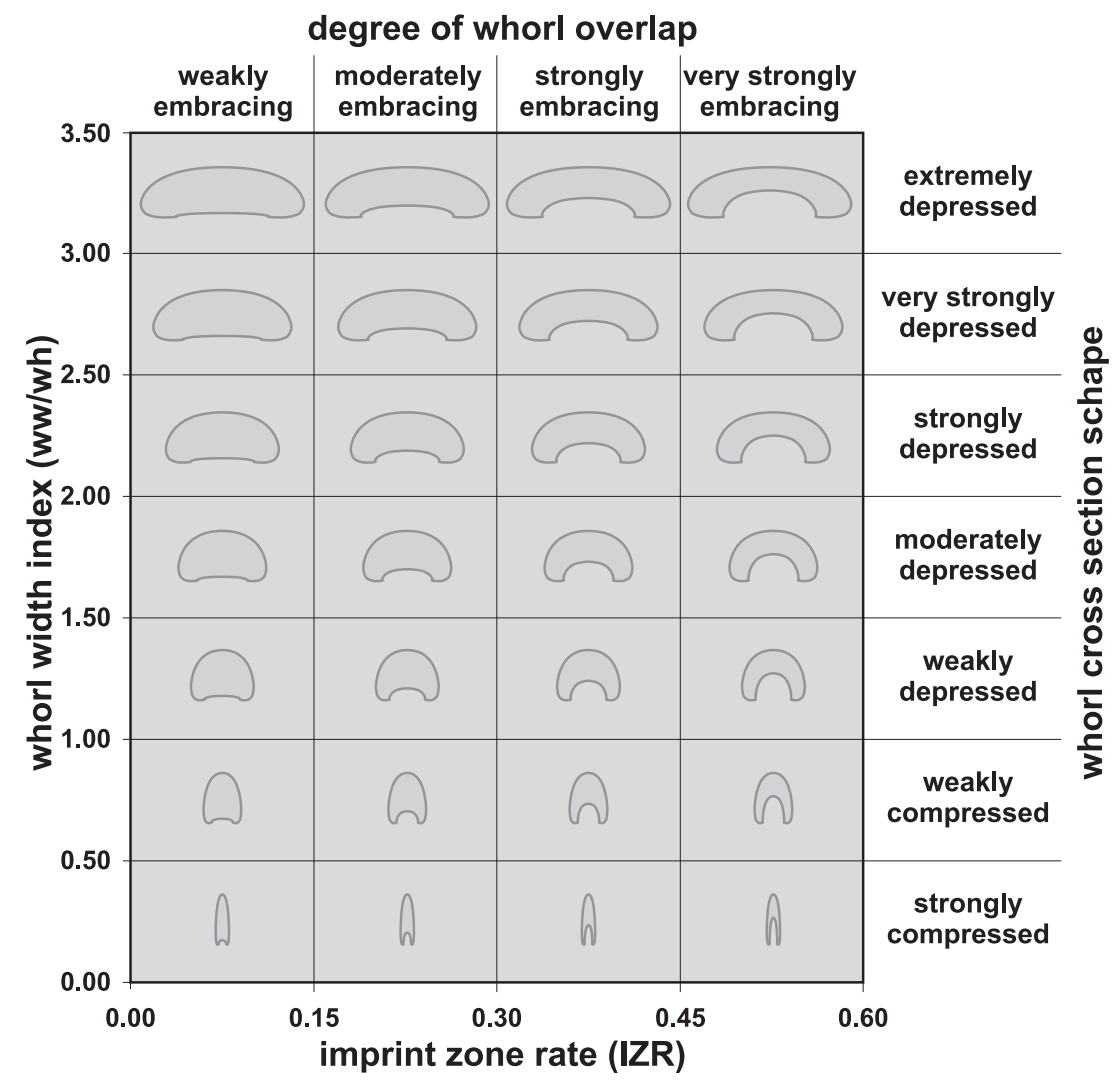

Figure 3. Bivariate plot illustrating the terminology of the imprint zone rate (IZR) on the $x$-axis and whorl width in$\operatorname{dex}(\mathrm{ww} / \mathrm{wh})$ on the $y$-axis.
Table 4. Classification of the umbilical width (umbilical

\begin{tabular}{lc}
\hline descriptive term & uw/wh \\
\hline very narrow & $<0.15$ (conch involute) \\
narrow & $0.15-0.30$ (conch subinvolute) \\
moderate & $0.30-0.45$ (conch subevolute) \\
wide & $0.45-0.60$ (conch evolute) \\
very wide & 0.60 (conch very evolute). \\
\hline
\end{tabular}

Table 5. Classification of the coiling rate of the conch (whorl expansion rate; WER).

\begin{tabular}{lc}
\hline descriptive term & WER \\
\hline very low & $<1.50$ \\
low & $1.50-1.75$ \\
moderate & $1.75-2.00$ \\
high & $2.00-2.20$ \\
very high & $2.25-2.50$ \\
extremely high & $>2.50$ \\
\hline
\end{tabular}

Table 6. Classification of the whorl overlap rate (imprint zone rate; IZR); see Fig. 3.

\begin{tabular}{ll}
\hline descriptive term & IZR \\
\hline weakly embracing & $<0.15$ \\
moderately embracing & $0.15-0.30$ \\
strongly embracing & $0.30-0.45$ \\
very strongly embracing & $>0.45$ \\
\hline
\end{tabular}
width index; uw/dm); see Fig. 2. 

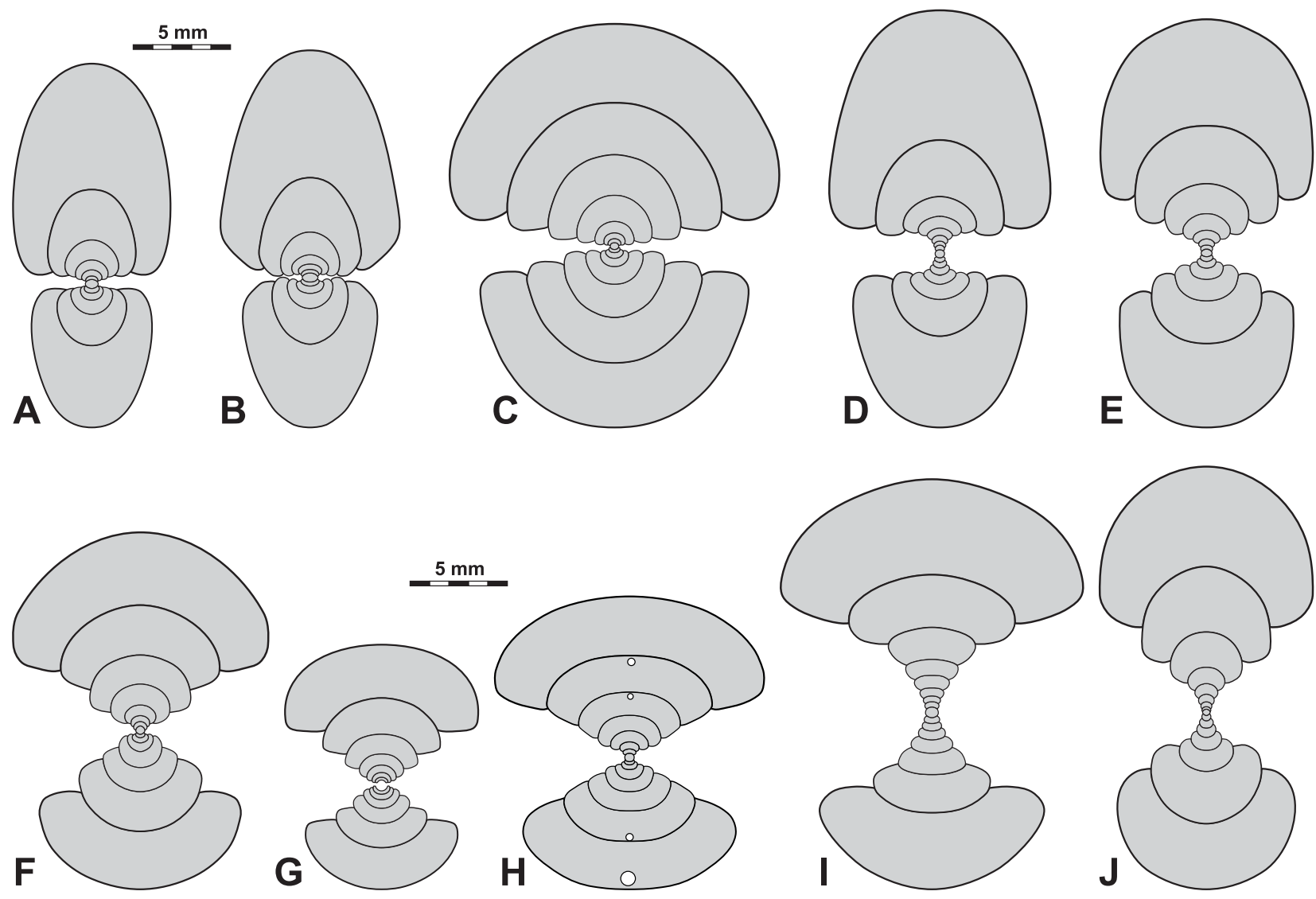

Figure 4. Various shapes of ammonoid conchs. A. Conch thinly discoidal, involute; venter narrowly rounded; flanks subparallel (conch widest in the midflank area); umbilical margin rounded, umbilical wall convex. B. Conch thinly discoidal, involute; venter narrowly rounded; flanks converging (conch widest near the umbilicus); umbilical margin subangular, umbilical wall oblique, flattened. C. Conch thickly pachyconic, involute; venter broadly rounded; flanks strongly converging; umbilical margin rounded, umbilical wall convex. D. Conch thickly discoidal, involute; venter rounded; flanks slightly converging; umbilical margin rounded, umbilical wall convex. E. Conch thickly discoidal, subinvolute; venter rounded; flanks subparallel; umbilical margin rounded, umbilical wall convex. F. Conch thinly pachyconic, subevolute; venter broadly rounded; flanks strongly converging; umbilical margin subangular, umbilical wall flattened. G. Conch thinly pachyconic, subevolute; venter broadly rounded; flanks subparallel; umbilical margin subangular, umbilical wall flat. H. Conch thinly globular, subevolute; venter very broadly rounded; umbilical margin subangular, umbilical wall flattened. I. Conch thickly pachyconic, evolute; venter broadly rounded; flanks strongly converging; umbilical margin subangular, umbilical wall flattened. J. Conch thickly discoidal, subevolute; venter very broadly rounded; flanks converging; umbilical margin rounded, umbilical wall rounded.

\section{Shell ornament and steinkern}

Growth lines, ribs, and constrictions can firstly be characterised by their direction and course across flanks and venter (Tab. 7). Therefore, the three ornament elements can be characterised by a uniform terminology.

Growth lines can occur in a wide range of strengths and consistencies, ranging from extremely fine to coarse with different spacing, they can be smooth, rough or crenulated. Strong crenulation may result in a spiral ornament, in which the spiral lines can range from fine to coarse. The number of spiral lines, counted from umbilicus to umbilicus, is often a criterion for the separation of species.

Ribs may be simple or more complex (i.e. with bifurcation and/or with intercalation of secondary ribs). They can range, in their strength, from being little more than strengthened growth lines to prominent ra-
Table 7. Classification of the direction and course of the growth lines, ribs, and constrictions (Fig. 5).

\begin{tabular}{ll}
\hline descriptive term & characteristics \\
\hline $\begin{array}{l}\text { rursiradiate } \\
\text { rectiradiate }\end{array}$ & with a general backward direction \\
prorsiradiate & with a general radial direction \\
linear & without remarkable projections and sinuses \\
convex & with only one wide projection on the flank \\
& (lateral projection) and a ventral sinus \\
concavo-convex & with a sinus on the midflank (lateral sinus), \\
& a projection at the boundary between flank \\
& $\begin{array}{l}\text { and venter (ventrolateral projection), and a } \\
\text { ventral sinus } \\
\text { with two projections on the flank (dorsolat- } \\
\text { eral and ventrolateral projection) and a lat- } \\
\text { eral as well as a ventral sinus }\end{array}$ \\
\hline
\end{tabular}



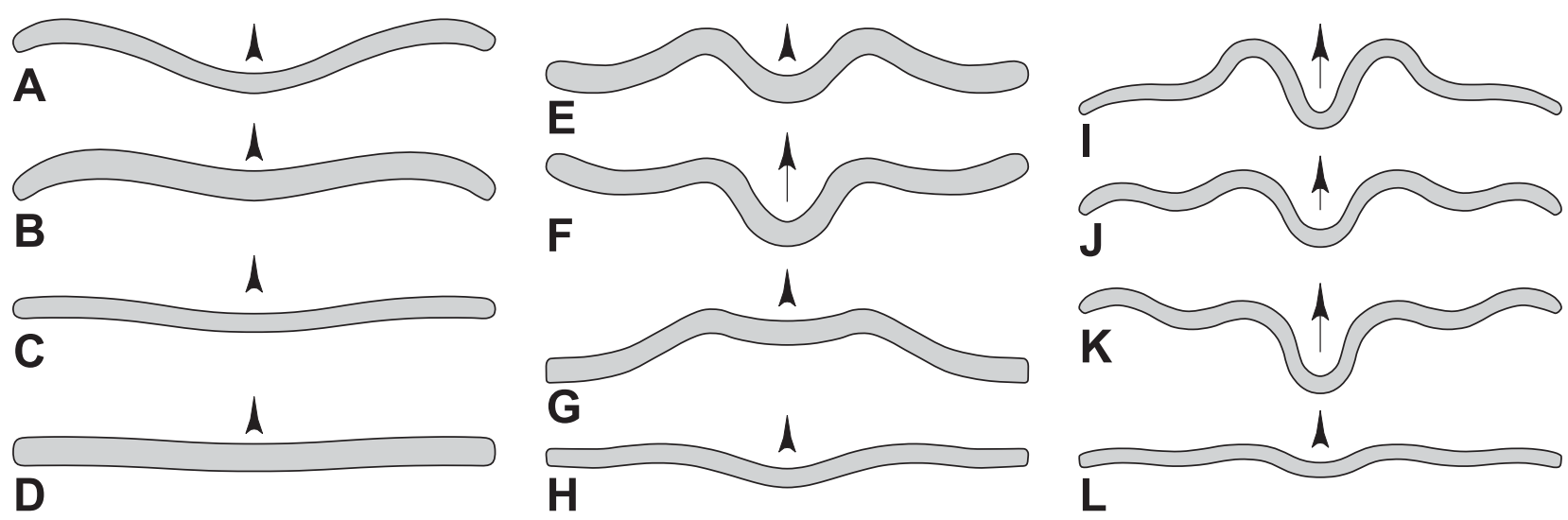

Figure 5. Various modes of constrictions. A. Convex with deep ventral sinus. B. Convex with shallow ventral sinus. C. Convex with extremely shallow ventral sinus. D. Linear. E. Concavo-convex with high ventrolateral projection and deep ventral sinus (direction prorsiradiate). F. Concavo-convex with low ventrolateral projection and deep ventral sinus (direction rectiradiate). G. Concavo-convex with high ventrolateral projection and very shallow ventral sinus (direction prorsiradiate). H. Concavo-convex with very low ventrolateral projection and very low ventral sinus (direction rectiradiate). I. Biconvex with low dorsolateral projection, high ventrolateral projection and deep ventral sinus (direction prorsiradiate). J. Biconvex with high dorsolateral projection, high ventrolateral projection and deep ventral sinus (direction rectiradiate). K. Biconvex with high dorsolateral projection, low ventrolateral projection and deep ventral sinus (direction rursiradiate). L. Biconvex with low dorsolateral projection, low ventrolateral projection and shallow ventral sinus (direction rectiradiate).

dial sculptures. Their direction and course is described as in the growth lines.

Constrictions can occur on the internal mould when they are caused by internal shell thickenings (= steinkern constrictions) or on the shell surface as well as the internal mould (= shell constrictions). Their direction and course is described as in the growth lines.

Longitudinal (spirally arranged) constrictions are described as grooves. They occur, in some groups within the Goniatitina, in the ventrolateral area and are visible on the internal mould as well as on the shell surface. Rare cases of a midventral groove are known particularly from the Prolecanitida.

\section{Suture line}

Sutural terminology (Fig. 6) for the Goniatitida is according to Wedekind (1918), and for the Prolecanitida according to Korn et al. (2003):

- external lobe (E lobe);

- median saddle (M saddle);

- ventrolateral saddle (E/A saddle; between external lobe and adventive lobe);

- adventive lobe (A lobe);

- dorsolateral saddle (A/L saddle; between adventive lobe and lateral lobe);

- lateral lobe (L lobe);

- umbilical lobe (U lobe);

- internal lobe (I lobe).

The width of the external lobe, which is an important criterion for the separation of species and genera particularly within the Goniatitina, can be described (1) by the ratio of the width (at half depth) of the external lobe and the adventive lobe (E/A as used by Korn 1988), or (2) by the ratio of width (measured at half depth) and total depth of the external lobe (EL/h as used by Korn 1997 or EL w/d as used here).

The general shape of the ventrolateral saddle can either be symmetric or asymmetric (e.g. with two strongly different flanks), it can range from being broadly rounded to narrowly rounded, subacute or acute.

The adventive lobe can be described as shallow (i.e. not as deep as the external lobe), moderately deep (about the same depth as the external lobe) or deep (deeper than the external lobe). Its general shape can be symmetric or asymmetric with incurved (concave), straight, or convex flanks.
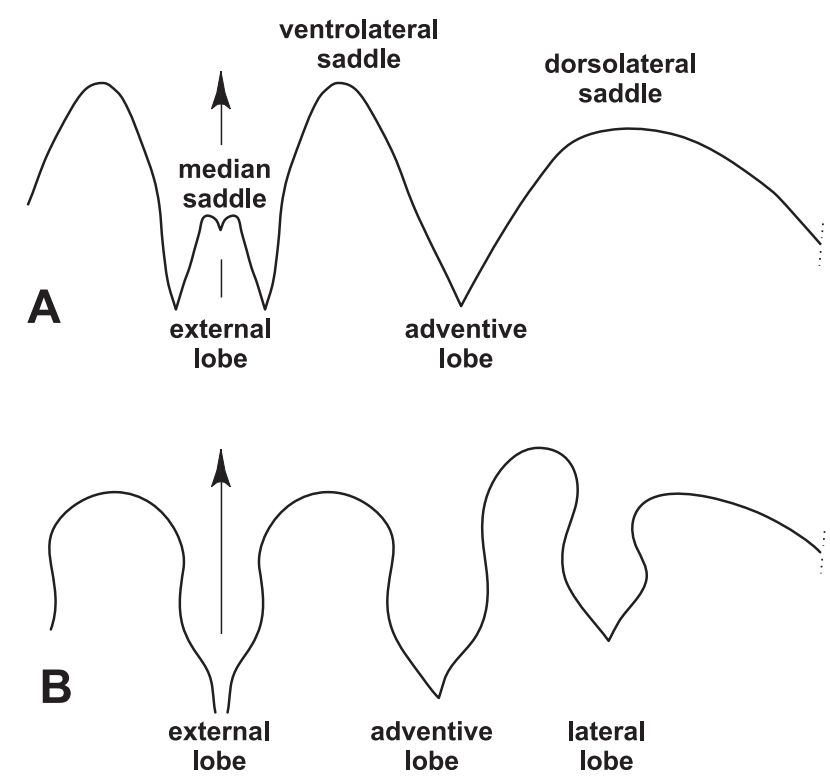

Figure 6. Descriptive terms for sutural morphology of Palaeozoic ammonoids. A. Goniatitid ammonoid. B. Prolecanitid ammonoid. 
In the tables with the suture line proportions (Tab. 13), further characteristics are demonstrated, (1) the relative width of the ventrolateral saddle, calculated by its width in comparison with the external lobe (EL/VLS) or its width/height proportion (VLS w/h), and (2) the relative width of the adventive lobe, calculated by its width in comparison with the external lobe (EL/AL).

Table 8. Shape of the external lobe as an important criterion for distinguishing major ammonoid taxa.

\begin{tabular}{|c|c|}
\hline descriptive term & characteristics \\
\hline rectangular & with largely parallel and almost uncurved flanks \\
\hline pouched or inflated & $\begin{array}{l}\text { with more or less parallel and convexly curved } \\
\text { flanks }\end{array}$ \\
\hline V-shaped & with diverging and almost straight flanks \\
\hline Y-shaped & $\begin{array}{l}\text { with flanks parallel in the lower part, } \\
\text { but diverging in the upper part }\end{array}$ \\
\hline bottle-shaped & $\begin{array}{l}\text { with flanks parallel in the lower part, } \\
\text { but narrower in the upper part. }\end{array}$ \\
\hline
\end{tabular}
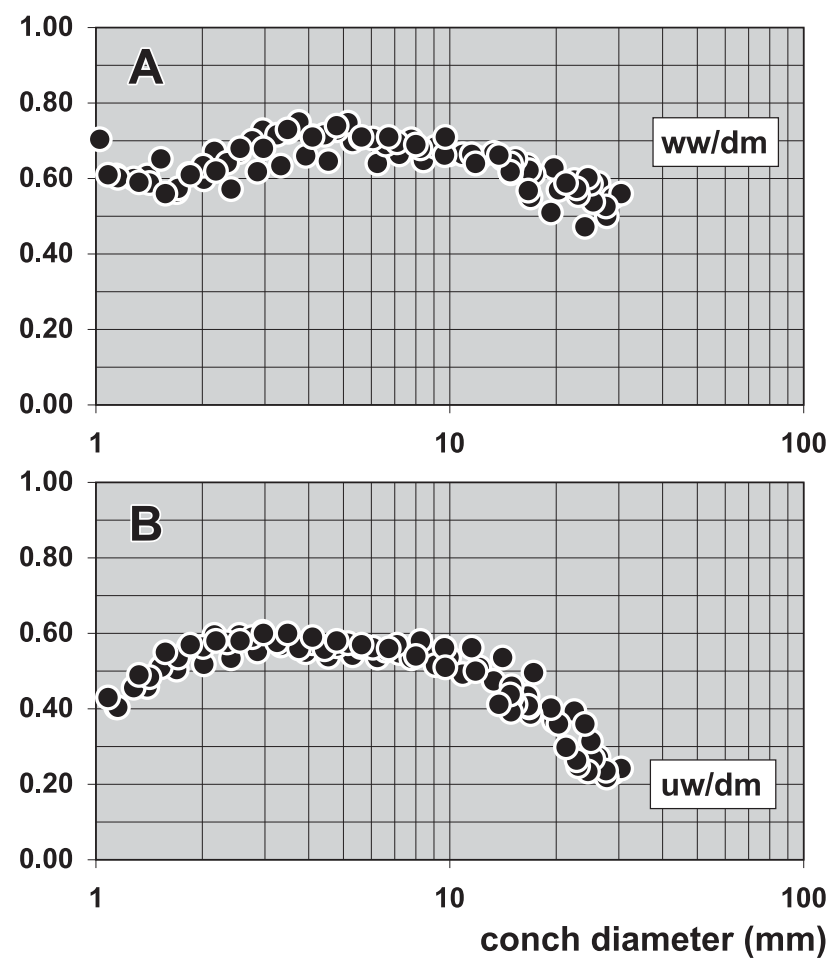

Table 9. Classification of the width of the external lobe (EL w/d).

\begin{tabular}{ll}
\hline descriptive term & EL w/d \\
\hline very narrow & $<0.50$ \\
narrow & $0.50-0.75$ \\
moderately narrow & $0.75-1.00$ \\
moderately wide & $1.00-1.25$ \\
wide & $1.25-1.50$ \\
very wide & $1.50-1.75$ \\
extremely wide & $>1.75$
\end{tabular}

Table 10. Classification of the height of the median saddle (MS h).

\begin{tabular}{lc}
\hline descriptive term & MS h \\
\hline very low & $<0.20$ \\
low & $0.20-0.35$ \\
moderately low & $0.35-0.50$ \\
moderately high & $0.50-0.65$ \\
high & $0.65-0.80$ \\
very high & $>0.80$ \\
\hline
\end{tabular}
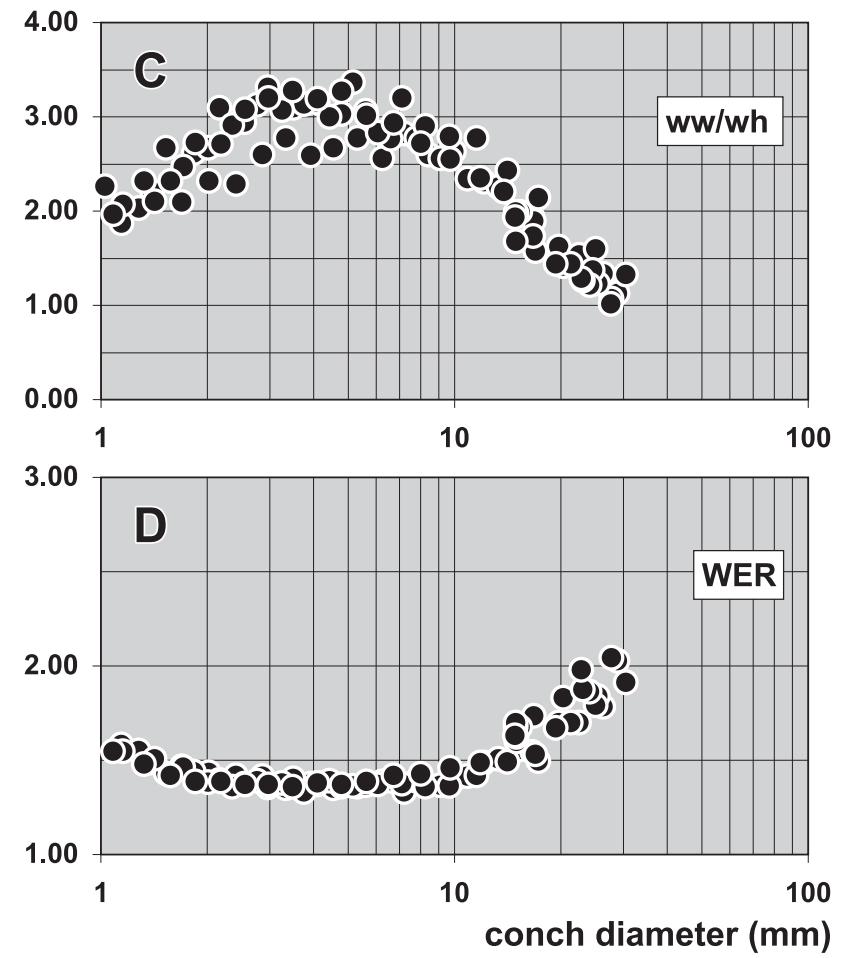

Figure 7. Example of an illustration of the ontogenetic development of the conch in ammonoids. A. Conch width index (ww/dm). B. Umbilical width index (uw/dm). C. Whorl width index (ww/wh). D. Whorl expansion rate (WER) of all available specimens of a distinct species.

\section{Descriptions of ammonoid species}

\section{Diagnosis}

Most of the Carboniferous ammonoid species are not characterised by a single or by a few apomorphic characters but much more frequently by a combination of quantitative characters. Therefore, diagnoses must often be arranged in a matrix-like matter, composed of a set of characters that allow the comparison between the species within distinct genera. Usually, the diagnosis pays attention to characters of conch morphology and ontogeny, ornament, and suture line. 

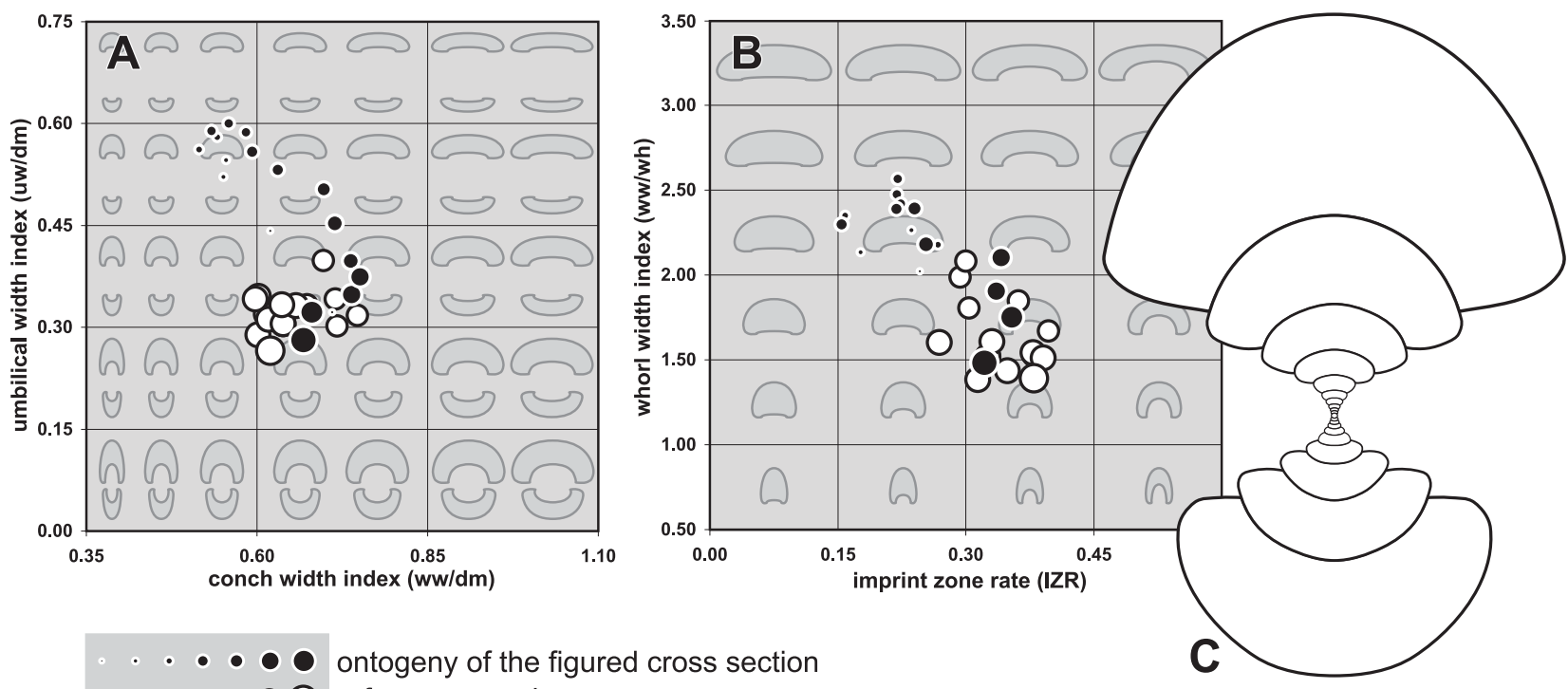

0 reference specimens

Figure 8. Example of a bivariate plot of the ontogenetic trajectories of an Early Carboniferous ammonoid (Hammatocyclus pollex Ebbighausen, Korn \& Bockwinkel, 2010).

\section{Description}

Traditionally, descriptions are based on a number of representative specimens. In cases with a large number of specimens and rich representation by cross sections showing the conch ontogeny, the illustration of ontogenetic trajectories and intraspecific variability as well as tabular depiction with the focus on selected growth stages is much more informative.

Ontogenetic trajectories and intraspecific variability of the main conch characters i.e. conch width index (ww/ $\mathrm{dm})$, umbilical width index (uw/dm), whorl width index (ww/wh), and whorl expansion rate (WER) can be visualised in simple semi-logarithmic plots (Fig. 7). In these, the conch diameter is logarithmically represented on the $x$-axis and the ratio or expansion rate is on the $y$-axis.

These diagrams allow only the illustration of single characters, and therefore, bivariate plots for distinct pairs of characters were developed. In these, two related characters can be visualised. The first of these diagrams shows the conch width index on the $x$-axis and the umbilical width index on the $y$-axis (Fig. 2). The second illustrates the whorl width index on the $x$-axis and the imprint zone rate on the $y$-axis (Fig. 3). The

Table 11. Example of a table to illustrate the conch ontogeny of a Carboniferous ammonoid species, describing the conch morphology and its variation in four distinctive growth stages.

\begin{tabular}{llll}
\hline $\mathrm{dm}$ & conch shape & whorl cross section shape & aperture \\
\hline $4 \mathrm{~mm}$ & thickly pachyconic; subinvolute & moderately depressed; very strongly embracing & low \\
& $($ ww/dm $=0.75-0.85 ;$ uw/dm $=0.20-0.30)$ & $($ ww/wh $=1.60-2.00 ;$ IZR $=0.45-0.50)$ & (WER $=1.55-1.75)$ \\
$10 \mathrm{~mm}$ & thickly pachyconic; subevolute & strongly depressed; strongly embracing & low \\
& $($ ww/dm $=0.75-0.80 ;$ uw/dm $=0.30-0.38)$ & $($ ww/wh $=2.00-2.25 ;$ IZR $=0.35-0.40)$ & $($ WER $=1.55-1.75)$ \\
$30 \mathrm{~mm}$ & thickly discoidal; involute to subinvolute & weakly depressed; strongly embracing & moderate to high \\
& $($ ww/dm $=0.50-0.60 ;$ uw/dm $=0.10-0.20)$ & $($ ww/wh $=1.00-1.50 ;$ IZR $=0.40-0.45)$ & (WER $=1.90-2.10)$ \\
$60 \mathrm{~mm}$ & thinly to thickly discoidal; involute & weakly compressed; strongly embracing & high \\
& $($ ww/dm $=0.45-0.50 ;$ uw/dm $=0.05-0.10)$ & $($ ww/wh $=0.80-1.00 ;$ IZR $=0.40-0.45)$ & (WER $=2.00-2.15)$ \\
\hline
\end{tabular}

Table 12. Example of a table to illustrate the conch dimensions and proportions for reference specimens of a Carboniferous ammonoid species.

\begin{tabular}{|c|c|c|c|c|c|c|c|c|c|c|}
\hline & $\mathrm{dm}$ & $w w$ & wh & uw & ah & $w w / d m$ & ww/wh & $\mathrm{uw} / \mathrm{dm}$ & WER & IZR \\
\hline paratype MB.C.18610.10 & 59.0 & 27.7 & 32.9 & 3.6 & 18.3 & 0.47 & 0.84 & 0.06 & 2.10 & 0.44 \\
\hline paratype MB.C.18610.2 & 51.5 & 26.1 & 27.8 & 3.3 & 15.1 & 0.51 & 0.94 & 0.06 & 2.00 & 0.46 \\
\hline holotype MB.C.18610.1 & 45.8 & 23.5 & 25.8 & 3.5 & 13.6 & 0.51 & 0.91 & 0.08 & 2.02 & 0.47 \\
\hline paratype MB.C.18610.12 & 38.7 & 21.5 & 20.8 & 3.7 & 12.1 & 0.56 & 1.03 & 0.09 & 2.12 & 0.42 \\
\hline
\end{tabular}


Table 13. Example of a table to illustrate the suture line proportions and characteristics of a Carboniferous ammonoid species. [EL w/d = width of the external lobe in relation to its depth, measured at half depth; EL/VLS = width of the external lobe in relation to the ventrolateral saddle; $\mathrm{EL} / \mathrm{AL}=$ width of the external lobe in relation to the adventive lobe; MS $\mathrm{h}=$ height of the median saddle in relation to the depth of the external lobe; VLS $\mathrm{w} / \mathrm{h}=$ width of the ventrolateral saddle in relation to its height, measured at half depth].

\begin{tabular}{llllllll}
\hline specimen & at dm & EL w/d & EL/VLS & EL/AL & MS h & VLS w/h remarks \\
\hline paratype MB.C.18610.10 & $54.5 \mathrm{~mm}$ & 0.42 & 0.50 & 1.00 & 0.21 & 0.85 & A lobe with almost straight flanks \\
holotype MB.C.18610.1 & $44.8 \mathrm{~mm}$ & 0.39 & 0.43 & 0.79 & 0.18 & 0.89 & A lobe with slightly curved flanks \\
paratype MB.C.18610.4 & $32.7 \mathrm{~mm}$ & 0.41 & 0.52 & 0.91 & 0.24 & 0.79 & A lobe asymmetric \\
\hline
\end{tabular}

ontogenetic stage is illustrated by the size of the dots, with small stages represented by small dots and large diameters of the specimens by large dots (Fig. 8). Using these diagrams, ontogenetic traits can be illustrated and help for the separation of species.

In the monographs published parallel to this account (Bockwinkel et al. 2010; Ebbighausen et al. 2010; Korn et al. 2010a, 2010b, 2010c), a tabular description of biometric characters of conch and suture line (Tabs 1113) was given priority over narrative descriptions.

\section{Acknowledgements}

I am indebted to Jürgen Bockwinkel and Volker Ebbighausen in particular for the discussion of the manuscript. I also thank Sonny Walton (Potsdam) for proofreading the manuscript and Christian Klug (Zürich) as well as an anonymous reviewer for a review of the article.

\section{References}

Bockwinkel, J., Korn, D. \& Ebbighausen, V. 2010. The ammonoids from the Argiles de Timimoun of Timimoun (Early and Middle Viséan; Gourara, Algeria). - Fossil Record 13 (1): 215-278.

Ebbighausen, V., Korn, D. \& Bockwinkel, J. 2010. The ammonoids from the Dalle à Merocanites of Timimoun (Late TournaisianEarly Viséan; Gourara, Algeria). - Fossil Record 13 (1): 153-202.

Korn, D. 1988. Die Goniatiten des Kulmplattenkalkes (Cephalopoda, Ammonoidea; Unterkarbon; Rheinisches Schiefergebirge). - Geologie und Paläontologie in Westfalen 11: 1-293.

Korn, D. 1997. The Palaeozoic ammonoids of the South Portuguese Zone. - Memórias do Instituto Geológico e Mineiro 33: 1-131.

Korn, D. \& Klug, C. 2003. Morphological pathways in the evolution of Early and Middle Devonian ammonoids. - Paleobiology 29: $329-348$
Korn, D. \& Klug, C. 2007. Conch Form Analysis, Variability, Morphological Disparity, and Mode of Life of the Frasnian (Late Devonian) Ammonoid Manticoceras from Coumiac (Montagne Noire, France). In Landman, N. H., Davis, R. A. \& Mapes, R. H. (eds). Cephalopods Present and Past: New Insights and Fresh Perspectives. Springer, Dordrecht: pp. 57-85.

Korn, D., Ebbighausen, V., Bockwinkel, J. \& Klug, C. 2003. The Amode sutural ontogeny in prolecanitid ammonoids. - Palaeontology 46 (6): 1123-1132.

Korn, D., Ebbighausen, V. \& Bockwinkel, J. 2010a. The ammonoids from the Grès du Kahla supérieur of Timimoun (Middle-early Late Tournaisian; Gourara, Algeria). - Fossil Record 13 (1): 1334.

Korn, D., Ebbighausen, V. \& Bockwinkel, J. 2010b. Ammonoids from the Dalle des Iridet of the Mouydir and Ahnet (Central Sahara) and the Formation d'Hassi Sguilma of the Saoura Valley (Late Tournaisian-Early Viséan; Algeria). - Fossil Record 13 (1): 203 214

Korn, D., Bockwinkel, J. \& Ebbighausen, V. 2010c. The ammonoids from the Argiles de Teguentour of Oued Temertasset (early Late Tournaisian; Mouydir, Algeria). - Fossil Record 13 (1): 35-152.

Kutygin, R. V. 1998. Forma rakovin permskikh ammonoidei severo-vostoka Rossii. - Paleontologicheskiy Zhurnal 1998 (1): 20-31.

Ruzhencev, V. E. 1956. Nizhnepermskiye ammonity Yuzhnogo Urala. II. Ammonity Artinskogo yarusa. - Trudy Paleontologicheskogo Instituta Akademiya Nauk SSSR 6: 1-275.

Ruzhencev, V. E. 1960. Printsipy sistematiki, sistema i filogeniya paleozoyskikh ammonoidey. - Trudy Paleontologicheskogo Instituta Akademiya Nauk SSSR 133: 1-331.

Sowerby, J. 1812-1814. Mineral Conchology of Great Britain, volume I. 234 pp.

Wedekind, R. 1918. Die Genera der Palaeoammonoidea (Goniatiten). Mit Ausschluß der Mimoceratidae, Glyphioceratidae und Prolecanitidae. - Palaeontographica 62: 85-184. 